\title{
Comparative Analysis of Business Performance of Cross Border Acquisitions in Serbia
}

\author{
Rakita Branko $^{1} \&$ Marković Dušan ${ }^{1}$ \\ ${ }^{1}$ Faculty of Economics, Belgrade University, Belgrade, Serbia \\ Correspondence: Marković Dušan, Faculty of Economics, Belgrade University, 6 Kamenicka Street, Belgrade, \\ 11000, Serbia. Tel: 381-64-316-0204. E-mail: dusanm@ekof.bg.ac.rs
}

Received: February 21, 2013

Accepted: March 14, 2013

Online Published: March 20, 2013

doi:10.5539/ibr.v6n4p170

URL: http://dx.doi.org/10.5539/ibr.v6n4p170

\begin{abstract}
This paper investigates performance of cross-border acquisitions in Serbia. The paper includes two parts. The first part considers the results of the hitherto done research into cross-border acquisitions as a value creation strategy. The success rate cross-border acquisitions have had and the factors behind post-acquisition business performance of target firms are presented. The second part of this paper gives the analysis of the performance of cross-border acquisitions in Serbia based on the sample drawn from 78 target firms. The analysis comprises three business performance ratios whose values before and after acquisition were compared. The average of performance ratios of the most profitable companies in Serbia is used as a benchmark against which the performance of cross-border acquisitions is then compared. The analysis shows that, in spite of the global economic crisis, foreign investors in Serbia enhanced business performance of a significant number of target firms. Additionally, the analysis shows that cross-border acquisitions in Serbia failed to meet the business performance benchmark due to post-acquisition duties that were to be met under the economic crisis.
\end{abstract}

Keywords: cross border acquisitions, performance, benchmark, post acquisitions duties, economic crises

\section{Introduction}

In the last two decades processes of globalization and liberalization of international economy have been accelerated greatly. These processes have brought about profound technological, socio-economic and political changes on the global level. These changes have been extensive, often radical, and not easily foreseen in the long term. Their intensity and extent affected business environment in all industries and created ample opportunities and threats. In response, multinational enterprises (MNE) have sped up their cross-border expansion, giving advantage to entry strategies in the form of foreign direct investment (FDI). Liberalization of FDI policy, enhancement of institutional efficiency in developing countries, harmonization and standardization of international accounting, and development of international financial markets have created the conditions for a dynamic growth in cross-border acquisitions in the previous years. This substantial increase in number and value of cross-border acquisitions has been hindered by the global economic crisis. Although cross-border acquisitions have gradually been recovering its value after 2009, at the end of 2011 they reached only the half of its historic peak achieved in 2007. Table 1 shows cross-border acquisitions value dynamics between 2005 and 2011.

Table 1. Value of cross-border acquisitions in million USD

\begin{tabular}{llllllll}
\hline & $\mathbf{2 0 0 5}$ & $\mathbf{2 0 0 6}$ & $\mathbf{2 0 0 7}$ & $\mathbf{2 0 0 8}$ & $\mathbf{2 0 0 9}$ & $\mathbf{2 0 1 0}$ & $\mathbf{2 0 1 1}$ \\
\hline Developed economies & 359,551 & 497,324 & 841,714 & 568,041 & 160,758 & 223,726 & 400,929 \\
Developing economies & 68,680 & 114,922 & 144,830 & 105,849 & 73,975 & 98,149 & 103,615 \\
Transition economies & 6,188 & 2,940 & 21,729 & 20,167 & 7,432 & 5,693 & 13,510 \\
World total & 434,419 & 615,186 & $1,008,273$ & 694,057 & 242,165 & 327,568 & 518,054 \\
\hline
\end{tabular}

Source: United Nations Conference of Trade and Development [UNCTAD] 2012.

The data presented in Table 1 shows that in the foregoing period the value of cross-border acquisitions made in developed countries make up the largest portion of the total cross-border acquisitions. This is due to strong financial markets and institutions in developed countries, pumped up financial markets, insufficient number and poor quality of targets in transition and developing countries. It is noticeable that the value of cross-border 
acquisitions made in transition countries makes up a negligible portion of the total value of cross-border acquisitions, though they make up a significant portion of total FDI inflow in some of these countries.

In the previous period the authors of this article have delivered papers looking at cross-border acquisitions and acted as expert advisers on several cross-border acquisitions in Serbia. The authors had a thorough insight into financial statements of target firms acquired during the transition period in Serbian market, which opened up the opportunity to do a representative empirical research. The authors thus identified the cases where foreign investors, in spite of their competitive superiority and financial strength, failed to successfully restructure acquired companies in Serbia. This can be to a large extant ascribed to the specific business environment in Serbia, due to belated and slow transition to market economy, and the global economic crisis continuing from 2008. Taking into account that cross-border acquisitions have made up a considerable portion of total FDI inflow in Serbia in the previous period, the analysis of their performance is highly significant and can bring about some very useful conclusions. The research conducted in Serbia can be useful to researchers analyzing business performance of cross-border acquisitions in other belated transition states, such as some West Balkan states, some former Soviet Union states and some states in Asia.

Analysis of cross-border acquisitions as a value creation strategy is given in the first part of this paper. Theoretical concepts of value creation through acquisitions and the results of previous empirical research are also presented. Analysis of relevant literature comprises academic papers on operational and financial synergy and the new theoretical concept by which cross-border acquisitions are defined as a tool for a radical change of the business model used by investor. The results of empirical research into value creation through cross-border acquisitions are then presented.

The second part of the paper investigates the effects of cross-border acquisitions in Serbia on target firms' profitability ratios on the basis of the analysis of financial reports of 78 medium-sized and large target firms in Serbia. Targets' profitability ratios prior to and after the acquisition were compared. Business performance of the most profitable companies in Serbia is used as a benchmark against which the performance of the acquired enterprises is compared. Two hypotheses were examined in this paper:

H1. Foreign investors in Serbia significantly enhanced targets' business performance compared with pre-acquisition period.

H2. Cross-border acquisitions in Serbia failed to meet the benchmark set by the most profitable companies in Serbia due to post acquisitions duties foreign investors had to meet under the global economic crises.

\section{Value Creation through Cross-Border Acquisitions}

In the last two decades, in the so called "Fifth Wave of mergers and acquisitions", the number of acquisitions, predominantly horizontal acquisitions, rapidly increased. In this period acquisitions were driven by positive economic trends in the USA and the Western Europe and deregulation of world economy (Gaughan, 2007). The Fifth Wave of acquisitions is to a large the consequence of MNEs' strategies of focusing on their core business and restructuring often highly diversified business operations. In the field of business economics acquisitions have been analyzed from different aspects aiming to determine the motives behind them, effects they produce, the factors behind their success or failure, and how to enhance the acquisition process itself.

According to its goals acquisitions can be classified into (Christensen, Alton, Rising \& Waldeck, 2011): (1) acquisitions through which companies try to enhance business performance without changing the business model (2) acquisitions through which companies try to reinvent their business model. Through the first type of acquisitions which are made more frequently companies tend to maintain current strategic position. Investors often have high expectations about these acquisitions so the premiums paid for targets can often be very high. On the other hand, less frequently the goal behind an acquisition is to reinvent the existing business model and to create a new strategic position. The basic problems involved in these acquisitions are target identification, how to evaluate target and how to achieve integration (Christensen, et al., 2011).

All acquisitions are driven by synergy motives. Synergy can be achieved via operating and financial synergy. Operating synergy aims at operational costs reduction and revenue increase, and financial synergy aims at cost of capital reduction. Operating synergy through acquisition will not be achieved equally fast and does not have equal prospects of success (Cullinan, Jean \& Rolf, 2004). Operating synergy map can be represented in the form of concentric circles where larger distance from the center corresponds to lower probability and longer period of achieving synergy. 


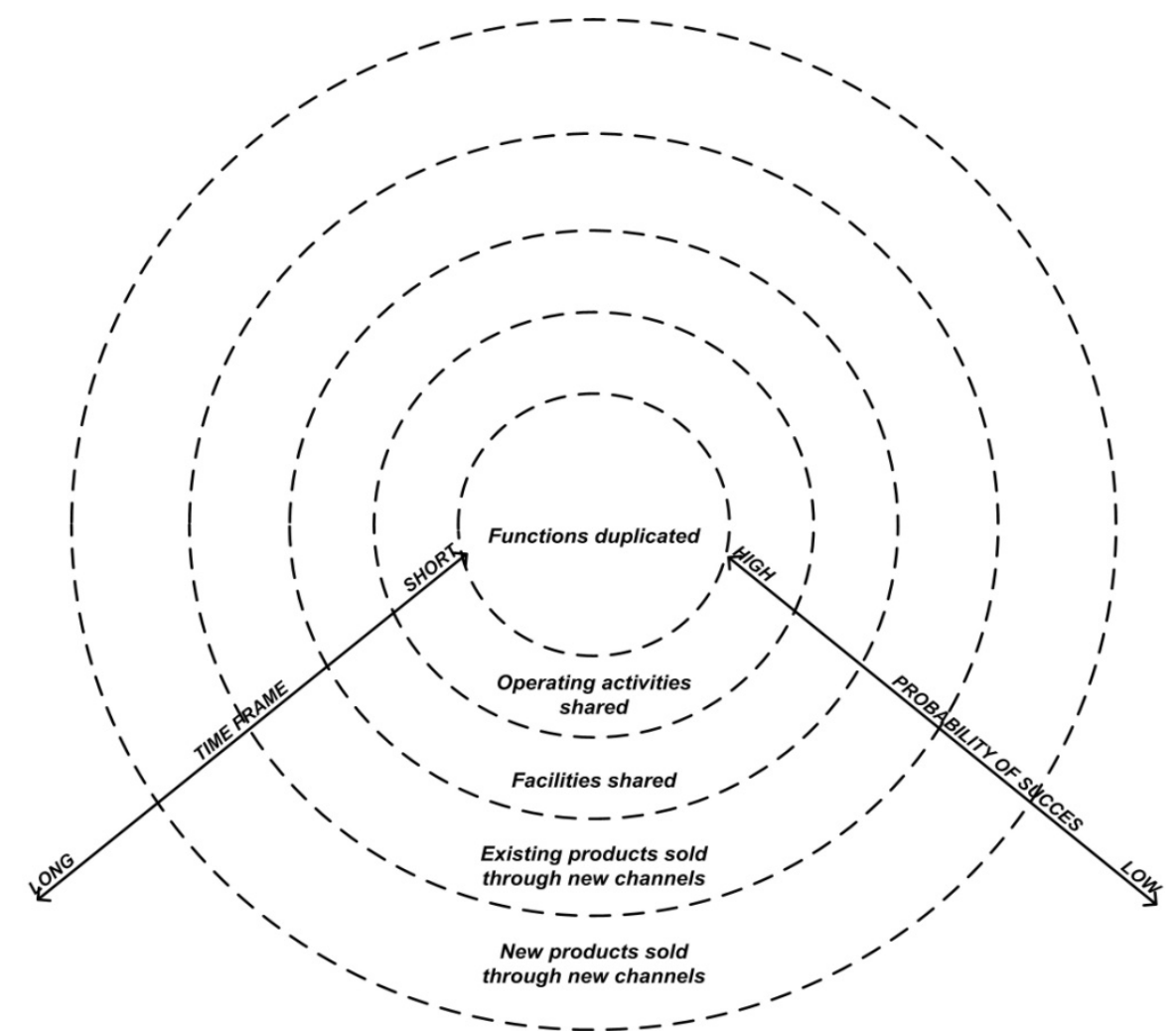

Figure 1. Operating synergy map (Cullinan et al., 2004)

When making Due Diligence, but also in post-acquisition period, cost reduction is investor's top priority. There are several reasons for this. Cost reduction targets can be quiet easily identified and quantified, and most often costs can be easily reduced in short term. So called "early victories" are won through rapidly achieved considerable cost reductions. "Early victories" must be promoted among the stakeholders, especially among the investors and creditors (Habeck, Kroger, \& Tram, 2000). In times of the global economic crisis many industries are faced with the problem of overcapacity, so one of the first measures investors in these industries take after acquisition is elimination of surplus capacities. Investors thus reduce fixed costs, and consequently decrease pressure on prices and increase profit margins (Sudarsanam, 2003). These measures comprise production and nonproduction employees and entire production facilities. Elimination of overcapacity is closely related to cost reduction through economies of scale. However, accomplishment of economies of scale to a large depends on the level of business performance achieved, operating costs and risks. Building competitive advantage only through economies of scale is a high-risk strategy in the world of hyper-competition and constant technology innovations.

Apart from economies of scale, considerable cost reductions can be achieved through economies of scope. Economy of scope means use of available resources not only in current business operations but also in similar business operations. Typically, economy of scope can be achieved through application of a flexible production line for manufacturing several different products. Economy of scope is, however, expected to be especially effective in the area of R\&D. Because $88 \%$ of innovations do not produce expected return on investment and soon after being introduced a large number of them are successfully imitated by competition, companies tend to fully utilize the innovations they have introduced (Ireland, Hoskisson \& Hitt, 2009). Acquisitions open up plenty of opportunities for achieving economies of scope, though it is quiet difficult to identify the factors that contribute to its accomplishment and to quantify its future effects.

Apart from cost reduction, the motive behind many horizontal acquisitions is to earn revenue that exceeds the simple sum of investor and target's revenues. When performing Due Diligence investors pay little regard to revenue increase opportunities. Revenue-based synergy can be achieved through complementary products, reputation spillover, distribution of new products through the existing channels, development of new products and new distribution channels etc. Revenue-based operating synergy involves considerable risks, and it can be achieved in the long run (see Figure 1).

In order to reduce cost of capital investors try to achieve financial synergy through acquisitions. If the cash flow 
of investor is not found to correlate highly with the cash flow of target, creditors can perceive the acquisition as an instrument of financial risk management. In that case cash flow variance will be reduced, the acquisition will be thus perceived less risky and the borrowing costs will be smaller.

Investors sometimes make acquisitions to reinvent the business models they use. By this investors try to set a new long-term growth basis, and thus gain higher competitive position (Christensen, Alton, Rising \& Waldeck, 2011). Such acquisitions are typically made if investors lack capacities to keep up with technology innovations or beat off severe competition. When investors estimate that their own production portfolio or market portfolio do not suffice for long-term growth, acquisition of a company possessing the lacking resources is necessary. This can mean penetration of unreachable geographic markets or new market segments, or launch of an entirely new product. This process of reinventing the existing business model via acquisitions involves considerable risks. Identification of the resources essential for reinventing business model, that is to say identification of target, is of crucial importance. Integration process, which usually requires transformation of both target and investor's organization structure, must be carefully planned and implemented. Evaluation of target via quantification of the effects of acquisition is quiet challenging.

In spite of the extensive theoretical and practical research into this field failure rate of acquisitions remains high. Most analyses show that more than $50 \%$ of acquisitions fail and the often cited research carried out by KPMG shows that on average $53 \%$ of acquisitions is value destroying, $30 \%$ have no effects on value, and only $17 \%$ of acquisitions create value for shareholders (KPMG, 1999). This research comprised both domestic and cross-border acquisitions. Cross-border acquisitions, compared with domestic acquisitions, entail additional risks as well as opportunities, due to national cultural differences, different regulations and institutional efficiency gap in acquirer's and host country. Empirical research has proved that value creation for stakeholders through cross-border acquisitions is on average higher than through domestic ones. This research attributes value creation through cross-border acquisitions to acquirer's capacity to exploit specific intangible resources abroad, which confirms the theory of internalization (Markides \& Oyon, 1998). It has been noticed in practice that performance of cross-border acquisitions depends on acquirer and target's country of origin. Analysis shows that cross-border acquisitions of targets from developed countries by acquirers from emerging economies create value for shareholders, which is attributed to complementarity of target's intangible resources and competitive advantage of acquirer's home country (Gubi, Aulaks, Ray, Sarkar \& Chittor, 2010). One of the major risks involved exclusively in cross border acquisitions is tension between acquirer and target caused by different national cultures. Results of the research into this field are inconsistent. The research which indicates that greater national cultural distance causes conflicts during integration process, and thus increases costs and decreases performance of acquisition (Brock, 2005), is at one end, while the research which suggests that greater national cultural distance means foundation for development of new business solutions on a complementary basis, stands at opposite end. A recent analysis shows that the degree of autonomy given to target after acquisition determines the effects of national cultural distance on performance of cross-border acquisitions. If the cultural distance is large, greater target firm autonomy produces beneficial effects on performance of cross-border acquisitions while high degree of integration exerts negative effects (Slangen, 2006).

Cross-border acquisitions of enterprises from transition countries have been investigated from different aspects. The researchers have generally focused on the influence of a new business environment and target's financial health on post-acquisition activities. Though it seems that rapid and radical changes are more expedient in terms of performance of acquisition, research has proved that target restructuring as evolutionary process is more beneficial in the long run (Meyer \& Lieb, 2003). Aggressive restructuring, extensive employee cutbacks and sale or elimination of surplus capacities can lead to waste of intangible resources crucial for doing business in transition countries, and which investors from developed market economies lack. Because acquirers must make considerable investments in target's limited technology and marketing capacities to dramatically enhance the whole business system, cross-border acquisitions in transition countries are remarkably similar to brownfield investments (Meyer \& Estrin, 2001). Consequently, overall investment greatly exceeds the purchase price, which should be considered when assessing the performance delivered after acquisition. If possible targets are poorly performing companies from transition countries, especially the state-owned ones, and the acquirers have competitive advantage and financial strength, a mistaken impression that business performance will undoubtedly be enhanced through such acquisitions is usually created. However, this is not always the case because many acquirers lack intangible resources crucial for successful performance in transition economies, and many investments made in the previous period failed to raise operating revenues due to the global crisis. Further in this paper the performance of cross-border acquisitions in Serbia will be analyzed on the basis of three financial ratios. 


\section{Business Performance of Cross-Border Acquisitions in Serbia}

\subsection{Methodology}

Cross-border acquisitions in Serbia make up a considerable portion of the total value of FDI inflow in the previous period, hence the need for an analysis of their performance. Profitability ratios analysis was made to assess the performance of the target firms. Analysis of the performance of an enterprise is often equated with profitability analysis because solvency, liquidity and asset management efficiency are presumed to directly or indirectly affect profitability.

Prior to the analysis database containing information on all cross-border acquisitions in Serbia made between 2000 and 2011 was created. The information was obtained from Serbian Privatization Agency, SIEPA (Serbia Investment and Export Promotion Agency), the information on the leading exporters from Serbia between 2005 and 2011, personal knowledge and the Internet. Information on 110 cross-border acquisitions was thus collected. Cross-border acquisitions made after 2009 (the period is too short to be analyzed), acquisitions of assets of a bankrupt target (cannot be compared over time), acquisitions where foreign company eventually merged with the target, acquisitions of enterprises that eventually filed for bankruptcy (four cases) or privatization contract was breached (one case) and acquisitions of small business entities (two cases) were than excluded from the database. A sample of 78 relevant acquisitions of large and medium-size enterprises steadily operating at least between 2006 and 2011 and in almost all cases longer was thus obtained.

Large number of profitability ratios used in practice can be classified into two groups: margins and returns. These ratios are interconnected. Operating profit margin, return on total assets or return on investment, and return on equity were analyzed in this research. Each ratio was measured throughout 2003 and from 2006 to 2011 (Note 1.), and then benchmarked against the average of the same ratio achieved by 100 enterprises that earned the highest net profit in the given year (Note 2.). Aforementioned ratios are disaggregated and then calculated as presented in formula 1,2 and 3 .

$$
\begin{aligned}
\text { Operating Profit Margin } & =\frac{O P}{S R} * 100 \\
\text { Return on Assets (ROA) } & =\frac{N P}{S R} * \frac{S R}{A A} * 100 \\
\text { Return on Equity (ROE) } & =\frac{N P}{S R} * \frac{S R}{A A} * \frac{A A}{A E} * 100
\end{aligned}
$$

OP - Operating Profit

NP - Net Profit

SR - Sales Revenues

AA - Average Assets

AE - Average Equity

\subsection{Results of the Analysis}

Business performance of a company considerably depends on the profitability of business operations. Operating profit margin is widely used to measure profitability of business operations. It measures profitability of a company without consideration of interest, taxes and nonoperating items. Table 2 shows the results of the analysis of operating profit margins generated by targets in Serbia before acquisition and in 2011.

Table 2. Results of comparative analysis of operating profit margins generated before acquisition and in 2011

\begin{tabular}{lll}
\hline & $\begin{array}{l}\text { Increase in the ratio compared with the year } \\
\text { before acquisition }\end{array}$ & $\begin{array}{l}\text { Decrease in the ratio compared with the year } \\
\text { before acquisition }\end{array}$ \\
\hline Number of target firms & 41 & 37 \\
Percentage of the sample & $52.56 \%$ & $47.44 \%$ \\
\hline
\end{tabular}

Table 2 shows that $53 \%$ of the companies included in the sample increased operating profit margin, which indicates higher profitability of business operations. Acquired state-owned targets make up 30 of 41 enterprises that increased operating profit margin. This is explained by target's quiet low operating profit margins or operating losses made before acquisition. The fact that 55 companies, or more than $70 \%$ of the sample, achieved operating profit in 2011 is of importance to Serbian economy. The analysis also shows that 32 companies 
achieved operating profit in all years after acquisition. Comparative analysis of profitability of target firms was performed through comparison of operating profit margins achieved from 2006 to 2011 against the benchmark of the corresponding year.

Table 3. Comparison of operating profit margins of acquired companies against the benchmark

\begin{tabular}{|c|c|c|c|c|c|c|}
\hline & 2006 & 2007 & 2008 & 2009 & 2010 & 2011 \\
\hline Domestic owned companies & 31 & 22 & 11 & 3 & $\mathbf{0}$ & $\mathbf{0}$ \\
\hline $\begin{array}{l}\text { Number of domestic owned companies which outperformed the } \\
\text { benchmark }\end{array}$ & 10 & 5 & 1 & 0 & 0 & 0 \\
\hline $\begin{array}{l}\text { Number of domestic owned companies which failed to meet the } \\
\text { benchmark }\end{array}$ & 21 & 17 & 10 & 3 & 0 & 0 \\
\hline $\begin{array}{l}\text { Percentage of domestic owned companies which outperformed the } \\
\text { benchmark }\end{array}$ & $32.26 \%$ & $22.73 \%$ & $9.09 \%$ & $0.00 \%$ & $0.00 \%$ & $0.00 \%$ \\
\hline $\begin{array}{l}\text { Percentage of domestic owned companies which failed to meet the } \\
\text { benchmark }\end{array}$ & $67.74 \%$ & $77.27 \%$ & $90.91 \%$ & $100.00 \%$ & $0.00 \%$ & $0.00 \%$ \\
\hline Number of target firms & 47 & 56 & 67 & 75 & 78 & 78 \\
\hline Number of target firms which outperformed the benchmark & 18 & 23 & 16 & 13 & 29 & 18 \\
\hline Number of target firms which failed to meet the benchmark & 29 & 33 & 51 & 62 & 49 & 60 \\
\hline Percentage of target firms which outperformed the benchmark & $38.30 \%$ & $41.07 \%$ & $23.88 \%$ & $17.33 \%$ & $37.18 \%$ & $23.08 \%$ \\
\hline Percentage of target firms which failed to meet the benchmark & $61.70 \%$ & $58.93 \%$ & $76.12 \%$ & $82.67 \%$ & $62.82 \%$ & $76.92 \%$ \\
\hline
\end{tabular}

Table 3 shows that the number of companies whose operating profit margin outperformed the benchmark of the analyzed period varied from $17 \%$ in 2009 to $41 \%$ in 2007. Companies with operating profit margin exceeding the benchmark considerably decreased in number due to the beginning of the global economic crisis. This negative trend was reversed in 2010 but in 2011 it continued. At the end of 2011 only $23 \%$ of the companies outperformed the operating profit margin benchmark.

Return on assets and return on equity were analyzed further in the research. In spite of some shortcomings these two ratios can be used as quite reliable indicators of overall business performance of a company. The number of target firms ranked in the top 100 enterprises with highest net profit in Serbia from 2006 to 2011 was assessed prior to the analysis. The results are presented in Table 4.

Table 4. Number of companies included in the sample that ranked in the top100 enterprises with the highest net profit in Serbia

\begin{tabular}{|c|c|c|c|c|c|c|}
\hline & 2006 & 2007 & 2008 & 2009 & 2010 & 2011 \\
\hline Number of domestic companies & 31 & 22 & 11 & 3 & $\mathbf{0}$ & $\mathbf{0}$ \\
\hline Companies included in the sample ranked in the top 100 by net profit & 6 & 4 & 2 & 0 & 0 & 0 \\
\hline Companies included in the sample which did not rank in the top 100 by net profit & 25 & 18 & 9 & 3 & 0 & 0 \\
\hline Number of target firms & 47 & 56 & 67 & 75 & 78 & 78 \\
\hline Targets included in the sample ranked in the top 100 by net profit & 15 & 18 & 17 & 16 & 15 & 19 \\
\hline Targets included in the sample which did not rank in the top 100 by net profit & 32 & 38 & 50 & 59 & 63 & 59 \\
\hline
\end{tabular}

From 2008 to 2010 the number of target firms that ranked in the top 100 companies with the highest net profit in Serbia declined. In 2011 the number increased to 19, which accounts for almost a quarter of the sample. Additionally, in the same year 51 companies generated net profit, and in every year after the acquisition was made 30 companies recorded net profit in their financial statements. It can be concluded that in spite of disadvantageous business environment cross-border acquisitions make up a quiet profitable portion of Serbian economy.

The analysis of business performance of cross-border acquisitions in Serbia measured by return on assets was then made. Table 5 shows the results of the analysis of return on assets received before acquisition and in 2011 . 
Table 5. The results of the analysis of return on assets received before acquisition and in 2011

\begin{tabular}{lll}
\hline & $\begin{array}{l}\text { Increase in the ratio compared with the year } \\
\text { before acquisition }\end{array}$ & $\begin{array}{l}\text { Decrease in the ratio compared with the year } \\
\text { before acquisition }\end{array}$ \\
\hline Number of targets & 49 & 29 \\
Percentage of the sample & $62.82 \%$ & $37.18 \%$ \\
\hline
\end{tabular}

A considerable number of foreign investors managed to enhance target's return on assets after acquisition. In 2011 return on assets received by 49 companies, which accounts for almost $63 \%$ of the sample, was higher than before acquisition. It is quite interesting that the portion of companies that did not increase return on assets is made up of acquisitions of private companies or state-owned companies that already had successful performance before acquisition was made. In the period of prosperity these companies made adequate return on assets, but at the beginning of the global economic crisis it declined. It can be concluded that foreign investors managed to enhance the return on assets of substantial number of targets after acquisition.

The results of comparative analysis of return on assets received by target firms are presented in Table 6 . The analysis was performed through comparison of return on assets received by each company separately from 2006 to 2011 against the benchmark of the corresponding year.

Table 6. Comparison of return on assets received by target firms against the benchmark

\begin{tabular}{|c|c|c|c|c|c|c|}
\hline & 2006 & 2007 & 2008 & 2009 & 2010 & 2011 \\
\hline Domestic owned companies & 31 & 22 & 11 & 3 & 0 & 0 \\
\hline $\begin{array}{l}\text { Number of domestic owned companies which outperformed the } \\
\text { benchmark }\end{array}$ & 7 & 2 & 0 & 0 & 0 & 0 \\
\hline $\begin{array}{l}\text { Number of domestic owned companies which failed to meet the } \\
\text { benchmark }\end{array}$ & 24 & 20 & 11 & 3 & 0 & 0 \\
\hline $\begin{array}{l}\text { Percentage of domestic owned companies which outperformed the } \\
\text { benchmark }\end{array}$ & $22.58 \%$ & $9.09 \%$ & $0.00 \%$ & $0.00 \%$ & $0.00 \%$ & $0.00 \%$ \\
\hline $\begin{array}{l}\text { Percentage of domestic owned companies which failed to meet the } \\
\text { benchmark }\end{array}$ & $77.42 \%$ & $90.91 \%$ & $100.00 \%$ & $100.00 \%$ & $0.00 \%$ & $0.00 \%$ \\
\hline Number of target firms & 47 & 56 & 67 & 75 & 78 & 78 \\
\hline Number of target firms which outperformed the benchmark & 6 & 5 & 2 & 6 & 11 & 7 \\
\hline Number of target firms which failed to meet the benchmark & 41 & 51 & 65 & 69 & 67 & 71 \\
\hline Percentage of target firms which outperformed the benchmark & $12.77 \%$ & $8.93 \%$ & $2.99 \%$ & $8.00 \%$ & $14.10 \%$ & $8.97 \%$ \\
\hline Percentage of target firms which failed to meet the benchmark & $87.23 \%$ & $91.07 \%$ & $97.01 \%$ & $92.00 \%$ & $85.90 \%$ & $91.03 \%$ \\
\hline
\end{tabular}

Data presented in Table 6 shows that there is a quiet small number of target firms whose return on assets outperformed the benchmark. The percentage of these companies varied from $14 \%$ in 2010 to only $3 \%$ in 2008 , and in 2011 it accounted for $9 \%$ of the sample. These results indicate that return on assets generated by target firms considerably fall short of the benchmark set by the companies with the highest net profit in Serbia, although $63 \%$ of companies in the sample increased the return on assets after being acquired.

Return on equity is considered especially important when assessing business performance of a company because it measures the performance from the shareholders' point of view. Table 7 shows the results of the comparative analysis of return on equity received by target firms before acquisition and in 2011.

Table 7. Results of the comparative analysis of return on equity received by targets before acquisition and in 2011

\begin{tabular}{llll}
\hline & $\begin{array}{l}\text { Increase in the ratio compared with } \\
\text { the year before acquisition }\end{array}$ & $\begin{array}{l}\text { Decrease in the ratio compared with } \\
\text { the year before acquisition }\end{array}$ & $\begin{array}{l}\text { Negative average } \\
\text { equity in 2011 }\end{array}$ \\
\hline $\begin{array}{l}\text { Number of targets } \\
\text { Percentage of the sample }\end{array}$ & 41 & 29 & 8 \\
\hline
\end{tabular}

Data presented in table 7 indicates that 41 companies increased return on equity after acquisition, which accounts for slightly over $52 \%$ of the sample. On the other hand, 8 companies comprised by the sample recorded negative average equity in 2011; therefore it was impossible to calculate the return on equity. Companies with return on equity lower than in the year prior to acquisition make up a considerable portion of the sample. This portion 
includes companies whose returns on equity before acquisition were quiet high but decreased due to the global economic crisis, and companies that recorded negative return on equity before acquisition and their performance deteriorated due to the global crisis.

Comparative analysis was performed through comparison of return on equity generated by each company separately from 2006 to 2011 against the benchmark of the corresponding year. Table 8 shows the results of the analysis.

Table 8 . Comparison of return on equity received by target firms against the benchmark

\begin{tabular}{|c|c|c|c|c|c|c|}
\hline & 2006 & 2007 & 2008 & 2009 & 2010 & 2011 \\
\hline Domestic owned companies & 31 & 22 & 11 & 3 & $\mathbf{0}$ & $\mathbf{0}$ \\
\hline Number of domestic owned companies which outperformd the benchmark & 6 & 2 & 0 & 0 & 0 & 0 \\
\hline $\begin{array}{l}\text { Number of domestic owned companies which failed to meet the } \\
\text { benchmark }\end{array}$ & 22 & 19 & 10 & 3 & 0 & 0 \\
\hline Number of domestic owned companies with negative average equity & 3 & 1 & 1 & 0 & 0 & 0 \\
\hline $\begin{array}{l}\text { Percentage of domestic owned companies which outperformed the } \\
\text { benchmark }\end{array}$ & $19.35 \%$ & $9.09 \%$ & $0.00 \%$ & $0.00 \%$ & $0.00 \%$ & $0.00 \%$ \\
\hline $\begin{array}{l}\text { Percentage of domestic owned companies which failed to meet the } \\
\text { benchmark }\end{array}$ & $70.97 \%$ & $86.36 \%$ & $90.91 \%$ & $100.00 \%$ & $0.00 \%$ & $0.00 \%$ \\
\hline Percentage of domestic owned companies with negative average equity & $9.68 \%$ & $4.55 \%$ & $9.09 \%$ & $0.00 \%$ & $0.00 \%$ & $0.00 \%$ \\
\hline Number of target firms & 47 & 56 & 67 & 75 & 78 & 78 \\
\hline Number of target firms which outperformed the benchmark & 3 & 3 & 0 & 0 & 2 & 0 \\
\hline Number of target firms which failed to meet the benchmark & 43 & 50 & 65 & 72 & 67 & 70 \\
\hline Number of targets with negative average equity & 1 & 3 & 2 & 3 & 9 & 8 \\
\hline Percentage of target firms which outperformed the benchmark & $6.38 \%$ & $5.36 \%$ & $0.00 \%$ & $0.00 \%$ & $2.56 \%$ & $0.00 \%$ \\
\hline Percentage of target firms which failed to meet the benchmark & $91.49 \%$ & $89.29 \%$ & $97.01 \%$ & $96.00 \%$ & $85.90 \%$ & $89.74 \%$ \\
\hline Percentage of targets with negative average equity & $2.13 \%$ & $5.36 \%$ & $2.99 \%$ & $4.00 \%$ & $11.54 \%$ & $10.26 \%$ \\
\hline
\end{tabular}

The analysis shows that almost all companies failed to meet the benchmark between 2006 and 2011. Three companies outperformed the benchmark in 2006 and 2007, and in 2010 there were two such companies. It is quite interesting that not a single company outperformed the benchmark in 2008, 2009 and 2011.

\subsection{Discussion of the Results of the Research}

The foregoing research shows that a considerable number of companies increased the three analyzed profitability ratios after the acquisition. This proves the hypothesis $\mathrm{H} 1$ that foreign investors enhanced business performance of targets in Serbia. The results obtained through comparative analysis were interpreted on the basis of the proven hypothesis H1. Results of the comparative analysis should be observed with consideration of the global economic crisis and investments necessary to enhance the performance of targets that most of the companies whose ratios were used to calculate the benchmark did not have to make (Note 3).

Before the global economic crisis foreign investors began restructuring of target firms which implied high investments in fixed assets. Higher labor force productivity achieved through restructuring reduced variable costs per unit, but due to the global economic crisis the growth in sales was not strong enough to achieve considerable reduction in fixed costs per unit. More than a half of the analyzed companies thus increased operating profit margin, but only approximately one quarter of the companies included in the sample outperformed the benchmark.

High investments in fixed assets that did not generate proportional operating revenues had negative impact upon total assets turnover ratio. Companies that enhanced total assets turnover ratio made up $36 \%$ of the sample, while $35 \%$ of the analyzed companies outperformed the benchmark at the end of 2011. Because total assets turnover ratio and operating profit margins achieved in 2011 were lower than the benchmark, less than $10 \%$ of the companies included in the sample failed to meet return on assets benchmark.

In order to finance high investments in fixed assets acquirers usually increased targets' debt. However, increased debt was not accompanied by increase in equity. Only $38 \%$ of companies included in the sample had lower level of financial leverage at the end of 2011 than in the year prior to acquisition. Only $23 \%$ of target firms were leveraged below the financial leverage benchmark at the end of 2011, which supports the belief that targets face higher degree of risk. Rising degree of financial leverage and the financial leverage exceeding the benchmark accompanied by quiet small number of companies that outperformed return on assets benchmark led up to 
negligible number of target firms that outperformed return on equity benchmark in the analyzed period.

Foregoing analysis show that foreign investors enhanced business performance of targets in Serbia but failed to meet the performance benchmark set by the most profitable companies in Serbia. High investments in fixed assets prior to the global economic crisis that did not generate adequate revenue growth in the succeeding years had impact upon the performance of target firms in Serbia relative to the benchmark, which proves the hypothesis $\mathrm{H} 2$.

\section{Conclusions}

"The Fifth Wave" of acquisitions that started about two decades ago was driven by global deregulation and positive economic trends continuing in developed European states and the USA by 2008. Because acquisitions, predominantly cross-border acquisitions, increased in value and number, this field of business economy has been widely researched. The aim was to identify the goals and effects of acquisitions, factors behind their success or failure, and how to enhance the process itself. Summarizing the results of the extant research we can conclude that companies make acquisitions to: 1 . Enhance business performance introducing no or gradual changes into the business system or 2. Reinvent the business system. While the success of acquisitions driven by the first motive depends on achievement of operating and financial synergy, the success of acquisitions driven by the second motive depends on radical change of competitive position through identification of lacking resources. According to some research only $17 \%$ of acquisitions create value for shareholders. Research into specific aspects of acquisitions indicates that on average success rate of cross-border acquisitions compared with domestic ones is higher, that acquisitions of targets from developed countries by acquirers from emerging economies proved very successful, and that large national cultural distance does not hinder cross-border acquisition performance if the target firm is given greater autonomy after acquisition.

Performance of cross-border acquisitions in Serbia was analyzed on the basis of the sample drawn from 78 medium-sized and large target firms. The analysis was performed through comparison of three profitability ratios (operating profit margin, return on assets and return on equity) before and after the acquisition, and through comparison of each profitability ratio against the benchmark (Note 4.). The research shows that:

- $53 \%$ of companies included in the sample had higher operating profit margin at the end of the analyzed period than before acquisition. Most of these companies are acquired state-owned targets that had quiet low operating profit margin or made operating losses before acquisition. Slightly above $23 \%$ of acquired targets outperformed operating profit margin benchmark at the end of 2011.

- $63 \%$ of analyzed companies increased return on assets after acquisition, and $53 \%$ increased return on equity. In 2011 in spite of improved profitability, only $9 \%$ of companies included in the sample outperformed the return on assets benchmark, and not a single company outperformed the return on equity benchmark.

Results obtained from this research indicate that in spite of the negative economic trends on the global level and in Serbia foreign investors enhanced business performance of target firms. It is noticeable that the performance of cross-border acquisitions in Serbia, especially when measured by return on equity and return on assets, is much lower than the benchmark set by the companies earning the highest net profit in Serbia. This is attributed to high investments in fixed assets made just before the global economic crisis which failed to generate expected operating revenue, due to disadvantageous business environment.

\section{Acknowledgements}

We are greatfull to Dragica Markovic for providing language help.

\section{References}

Brock, D. (2005). Multinational Acquisition Integration: The Role of National Culture in Creating Synergies. International Business Review, 14, 269-288. http://dx.doi.org/10.1016/j.ibusrev.2005.02.001

Christensen, M. C., Alton, R., Rising, C., \& Waldeck, A. (2011). The New M\&A Playbook. Harvard Business Review, 89, 49-57.

Cullinan, G., Jean, M. L. R., \& Rolf, M. W. (2004). When to Walk Away from a Deal. Business Harvard Review, 82, 97-104.

Gaughan, P. (2007). Mergers, Acquisitions and Corporate Restructuring (4th ed.). Hoboken, New Jersey: Wiley \& Sons.

Gubi, S., Aulaks, P., Ray, S., Sarkar, M., \& Chittoor, R. (2010). Do International Acquisitions by Emerging Economy Firms Create Shareholder Value? The Case of Indian Firms. Journal of International Business 
Studies, 41, 397-418. http://dx.doi.org/10.1057/jibs.2009.47

Habeck, M., Kroger, F., \& Tram, M. (2000). After the Merger: Seven Strategies for Successful Post Merger Integration. New York, NY: FT Press.

Ireland, D., Hoskisson, R., \& Hitt, M. (2009). The Management of Strategy, Concept and Cases (8th ed.). Canada: South Western, Cengage Learning.

KPMG. (1999). Unlocking Shareholder Value: The Keys to Success. London, United Kingdom: KPMG.

Markides, C., \& Oyon, D. (1998). International Acquisitions: Do They Create Value for Shareholders? European Management Journal, 16, 125-135. http://dx.doi.org/10.1016/S0263-2373(97)00082-0

Meyer, E. K., \& Estrin, S. (2001). Brownfield Entry in Emerging Markets. Journal of International Business Studies, 32, 575-584. http://dx.doi.org/10.1057/palgrave.jibs.8490985

Meyer, K., \& Lieb, D. E. (2003). Post Acquisition Restructuring as Evolutionary Process. Journal of Management Studies, 40, 459-482. http://dx.doi.org/10.1111/1467-6486.00347

Slangen, A. (2006). National Culture Distance and Initial Foreign Acquisition Performance: The Moderating Effect of Integration. Journal of World Business, 41, 161-170. http://dx.doi.org/10.1016/j.jwb.2006.01.003

Sudarsanam, S. (2003). Creating Value from Mergers and Acquisitions (4th ed.). New York, NY: Pearson Education.

UNCTAD. (2012). World Investment Report: Towards a new Generation of Investment Policies. Switzerland: UNCTAD.

\section{Notes}

Note 1. In 2003 majority companies had domestic ownership or were acquired short before, therefore the financial ratios measured before or immediately after the acquisition can be compared with the ratios measured from 2006 to 2011.

Note 2. The average of a financial ratio of 100 companies that earned the highest net profit in the given year is used as a benchmark against which the same financial ratio of each company in the sample is compared.

Note 3. When acquiring a state-owned company investor is bound by acquisition contract to invest in target.

Note 4. The average of a financial ratio of 100 companies that earned the highest net profit in the given year is used as a benchmark against which the same financial ratio of each company in the sample is compared. 